\title{
Comparative Evaluation of Antioxidant Activities of Ethanol Extracts and Their Solvent Fractions Obtained from Selected Miscellaneous Cereal Grains
}

\author{
Dong Hwa Park', Seung Tae Lee1, Do Youn Jun', Ji Young Lee', Mi Hee Woo', Ki Young Kim³, \\ Myung Chul Seo ${ }^{4}$, Jee Yeon $\mathrm{Ko}^{3}$, Koan Sik Woo, Tae Wook Jung ${ }^{3}$, Do Yeon $\mathrm{Kwak}^{3}$, Min $\mathrm{Hee} \mathrm{Nam}^{3}$ \\ and Young $\mathrm{Ho} \mathrm{Kim}{ }^{1}$ * \\ ${ }^{1}$ Laboratory of Immunobiology, School of Life Science and Biotechnology, College of Natural Sciences, Kyungpook National University, Daegu \\ 702-701, Korea \\ ${ }^{2}$ Department of Pharmacology, College of Pharmacology, Daegu Catholic University, Daegu 712-702, Korea \\ ${ }^{3}$ Functional Cereal Crop Research Division, NICS, RDA, Miryang 627-803, Korea \\ ${ }^{4}$ Crop Environment Division, NICS, RDA, Suwon 441-857, Korea
}

Received December 8, 2013 / Revised January 8, 2014 /Accepted January 14, 2014

\begin{abstract}
To examine the antioxidant activities of $11 \mathrm{n}$ selected miscellaneous cereal grains (proso millet, yellow glutinous proso millet, hwanggeumchal sorghum, glutinous sorghum, white glutinous sorghum, yellow glutinous foxtail millet, nonglutinous foxtail millet, green glutinous foxtail millet, golden foxtail millet, barnyard millet, and adlay), the free radical-scavenging activities of $80 \%$ ethanol extracts of the individual grains were investigated using 1,1-diphenyl-2-picryl-hydrazl (DPPH) and 2,2'-azino-bis (3-ethylbenzothiazoline-6-sulfonic acid) (ABTS) methods. The ethanol extracts of hwanggeumchal sorghum, glutinous sorghum, and barnyard millet grains exhibited more potent free radical-scavenging activities as compared to the other grains. When these three ethanol extracts were sequentially fractionated with $\mathrm{n}$-hexane, methylene chloride, ethyl acetate, and n-butanol, the majority of the antioxidant activities were detected in the ethyl acetate and butanol fractions in which phenolic ingredients were abundant. The ethyl acetate and butanol fractions of hwanggeumchal sorghum and the ethyl acetate fraction of glutinous sorghum showed higher antioxidant activity than that of a-tocopherol. Both ferric thiocyanate (FTC) and thiobarbituric acid (TBA) methods demonstrated that these organic solvent fractions could inhibit lipid peroxidation. The ethyl acetate fractions from hwanggeumchal sorghum, glutinous sorghum, and barnyard millet grains could suppress tertiary-butyl hydroperoxide (TBHP)-induced apoptotic events, including sub- $\mathrm{G}_{1}$ peaks, $\Delta \psi \mathrm{m}$ loss, activation of caspase- 9 and caspase-3, and cleavage of PARP and lamin B, in human HL-60 cells. These results show that the grains of hwanggeumchal sorghum (Sorghum bicolor L. Moench cv. Hwanggeumchalsusu), glutinous sorghum (Sorghum bicolor L. Moench cv. Chalsusu), and barnyard millet (Echinochloa esculenta) possess efficient antioxidant activity, which could protect cells from oxidative stress-mediated cytotoxicity.
\end{abstract}

Key words : Antioxidant activity, barnyard millet (Echinochloa esculenta) grains, cytoprotection, oxidative stress-induced apoptosis, sorghum (Sorghum bicolor) grains

\section{Introduction}

In living cells under normal conditions, many physiological and biochemical processes are known to generate reactive oxygen species (ROS) as the by-product. For example,

\footnotetext{
*Corresponding author

Tel : +82-53-950-5378, Fax : +82-53-955-5522.

E-mail : ykim@knu.ac.kr

This is an Open-Access article distributed under the terms of the Creative Commons Attribution Non-Commercial License (http://creativecommons.org/licenses/by-nc/3.0) which permits unrestricted non-commercial use, distribution, and reproduction in any medium, provided the original work is properly cited. The online version of this article (doi 10.5352/JLS.2014.24.1.26) contains supplementary material, which is available to authorized users.
}

mitochondria consume $\mathrm{O}_{2}$ to make energy and eventually produce $\mathrm{H}_{2} \mathrm{O}$. However, in this process, $\mathrm{O}_{2}^{-}, \mathrm{H}_{2} \mathrm{O}_{2}$, and $\mathrm{OH}^{-}$ are generated [5]. In inflammatory conditions, when phagocytic cells destroy the bacteria or virus, they use an oxidative burst of nitric oxide (NO), $\mathrm{O}_{2}^{-}, \mathrm{H}_{2} \mathrm{O}_{2}$, and $\mathrm{OCl}^{-}$. During fatty acid degradation in peroxisome, $\mathrm{H}_{2} \mathrm{O}_{2}$ is known to be generated as a by-product [20]. An excessive production of ROS has been implicated in oxidative damage to biomolecules such as carbohydrates, lipids, proteins, nucleic acids, which would lead to the damage of membranes and cellular organelles, and cause cancer [11, 21], cardiovascular diseases [36, 45], inflammatory disorders [4], aging and other diseases in humans $[9,10]$. For protection from the oxidative damage, human body is known to take advantage of not 
only endogenous antioxidant enzymes, such as superoxide dismutase (SOD), catalase, peroxidase, but also exogenous low molecular weight compounds such as tocopherol, ascorbic acid, and polyphenols.

Recently, much attention has been paid to the physiological functionality of foods, due to the increasing interest in human health, and research into the health benefits of foods has been increasing last years. One of the important beneficial functions of foods, beyond the provision of basic nutritional requirements, is mediated by antioxidant action that is supposed to reduce the risk of oxidative stress-related chronic diseases $[2,12]$. Since plants have a defense system to come up against the ROS conditions, which is manifested by free radical-scavenging components, such as vitamins, phenolic compounds, and some other intracellular metabolites, plant foods have been considered as an excellent source of antioxidants for human body [6, 27, 44]. While fruits, vegetables, and grains among plants are rich sources of antioxidant substances, the antioxidants found in these plants are mostly phenolic compounds. The grains-derived phenolic compounds are known to be very advantageous in that stability in dry conditions and storage conveniences compared with the fruit- or vegetable-derived compounds.

Agriculture in Korea has traditionally focused on the production of the major grains such as rice, barley and wheat, whereas the cultivation and harvesting of other miscellaneous cereals has remained in a low level. In recent years, however, due to increased demand for well-being foods, the interest in miscellaneous cereal grains as crude fibers and bioactive phytochemical sources that benefit human health and thus the consumption of miscellaneous cereal grains are also increasing in the country. Although several studies have been performed to extend our understanding on nutritional importance, antioxidant, antimicrobial, antimutagenic and anticarcinogenic, and antidiabetic properties of miscellaneous cereal grains harvested in Korea [13, 22, 25, 26, 32], the systematic study on their bioactive components associated with the antioxidant efficacy is still rare. If miscellaneous cereal grains are proven as a proper source of antioxidant phytochemicals, it is likely that these grains become highly effective in preventing oxidative stress-oriented chronic diseases by consuming as diet [28, 38, 40]. Furthermore, it is generally accepted that natural antioxidant components derived from edible plants may be more safely applicable for human health, as compared to synthetic antioxidants.
As an attempt to examine antioxidant activities of eleven selected miscellaneous cereal grains (proso millet, yellow glutinous proso millet, hwanggeumchal sorghum, glutinous sorghum, white glutinous sorghum, yellow glutinous foxtail millet, non-glutinous foxtail millet, green glutinous foxtail millet, golden foxtail millet, barnyard millet, and adlay) harvested in Korea, in the present study, we intended to compare the free radical-scavenging activities of $80 \%$ ethanol extracts of the individual grains using 1,1-diphenyl-2-picrylhydrazl (DPPH) and 2,2'-azino-bis (3-ethylbenzothiazoline6-sulfonic acid) (ABTS). The 80\% ethanol extracts of hwanggeumchal sorghum, glutinous sorghum and barnyard millet grains, which appeared to possess more potent free radical-scavenging activities compared with those of other grains, were sequentially fractionated by n-hexane, methylene chloride, ethyl acetate and n-butanol. Since the DPPH radical- and ABTS radical-scavenging activities were mainly detected in the ethyl acetate fraction followed by the butanol fraction, the antioxidant activity of the ethyl acetate fractions have been examined further by investigating not only their inhibitory effect on lipid peroxidation using ferric thiocyanate (FTC) and thiobarbituric acid (TBA) methods, but also their cytoprotective effect on tertiary-butyl hydroperoxide (TBHP)-induced apoptotic cell death in human HL-60 cells.

\section{Materials and Methods}

Chemicals, reagents, cells and culture medium

Dimethyl sulfoxide (DMSO), Folin-ciocaleau reagent, 1,1-diphenyl-2-picryl-hydrazl (DPPH), 2,2'-Azino-bis (3-ethylbenzothiazoline-6-sulfonic acid) diammonium salt (ABTS), tertiary-butyl hydroperoxide (TBHP), ferric thiocyanate (FTC), thiobarbituric acid (TBA), a-tocopherol, linoleic acid, ammonium thiocynate, thiobarbituric acid, and tannic acid were purchased from Sigma (St, Louis, MO, USA). Tannic acid was obtained from Avondale Laboratories (Oxon, England). The anti-caspase-3 antibody was purchased from Pharmingen (San Diego, CA, USA). Anti-poly (ADP-ribose) polymerase (PARP), Lamin $B$ and $\beta$-actin were obtained from Santa Cruz Biotechnology (Santa Cruz, CA, USA). The anti-caspase-9 was purchased from Cell signaling Technology (Beverly, MA, USA). An ECL Western blotting kit was obtained from Amersham (Arlington Heights, IL, USA) and Immobilon-P membrane was purchased from Millipore (Bedford, MA, USA). Human promyelocytic leuke- 
mia cell line HL-60 was obtained from ATCC (Manassas, VA, USA) and maintained in RPMI 1640 (Hyclone, Gaithersburg, MD, USA) containing $10 \%$ fetal bovine serum, $20 \mathrm{mM}$ HEPES (pH 7.2), $5 \times 10^{-5} \mathrm{M}$ ß-mercaptoethanol, and $100 \mu \mathrm{g} / \mathrm{ml}$ gentamycin. All other chemicals and organic solvents (ethanol, n-hexane, methylene chloride, ethyl acetate, and $\mathrm{n}$-butanol) were of analytical grade.

\section{Sample extraction}

Eleven miscellaneous cereal grains, including proso millet (polished grains), yellow glutinous proso millet (unpolished grains), hwanggeumchal sorghum (unpolished grains), glutinous sorghum (polished grains), white glutinous sorghum (unpolished grains), yellow glutinous foxtail millet (polished grains), non-glutinous foxtail millet (polished grains), green glutinous foxtail millet (polished grains), golden foxtail millet (unpolished grains), barnyard millet (unpolished grains), and adlay (polished grains), harvested in Korea were provided by National Institute of Crop Science, Rural Development Administration, Miryang, Gyeongnam 627-803, Korea. Individual dried grains were milled on a Blender 7012 (Dynamics Corporation, USA), and then extracted with 80\% ethanol for $3 \mathrm{~h}$ at $80^{\circ} \mathrm{C}$. The ethanol extract was evaporated, dissolved in water, and then sequentially extracted with n-hexane, methylene chloride, ethyl acetate, and n-butanol. Each organic solvent fractionation was repeated three times. The organic solvent fraction was concentrated by rotary vacuum evaporator (Heidolph LR 4000, Germany). The dry weights of the $80 \%$ ethanol extracts and organic solvent fractionations were described in Supplement 1 [23].

\section{1,1-Diphenyl-2-picryl-hydrazl (DPPH) radical- scavenging activity assay}

The 1,1-diphenyl-2-picryl-hydrazl (DPPH) radical-scavenging activity was carried out by modifying the method of Blois [3]. DPPH stock solution $(0.2 \mathrm{mM})$ was prepared in ethanol. To $800 \mu \mathrm{l}$ of DPPH stock solution, $50 \mu \mathrm{l}$ of sample dissolved in dimethyl sulfoxide (DMSO) was added. After the mixture was incubated in $37^{\circ} \mathrm{C}$ for $30 \mathrm{~min}$, the absorbance was measured at $517 \mathrm{~nm}$. The DPPH-radical-scavenging activity $(\%)=[($ Absorbance of control - Absorbance of sample)/Absorbance of control] $\times 100$ [8]. Lower absorbance values of the mixtures indicate higher free radical scavenging activity. The $\mathrm{EC}_{50}$ values denote the effective concentration of sample that is required to scavenge $50 \%$ of the DPPH free radicals [17]. All determinations were conducted in triplicates.

\section{2,2'-Azino-bis(3-ethylbenzothiazoline-6-sulfonic} acid) (ABTS) radical-scavenging activity assay

The 2,2'-azino-bis(3-ethylbenzothiazoline-6-sulfonic acid) (ABTS) solution was prepared by reaction of $1 \mathrm{ml}$ of $7 \mathrm{mM}$ ABTS stock solution dissolved in $\mathrm{d}^{\prime} \mathrm{H}_{2} \mathrm{O}$ and $17.6 \mu \mathrm{l}$ of 140 $\mathrm{mM} \mathrm{K} \mathrm{K}_{2} \mathrm{~S}_{2} \mathrm{O}_{8}$ dissolved in $\mathrm{d}^{\prime} \mathrm{H}_{2} \mathrm{O}$. After incubation in the dark for $16 \mathrm{~h}$, ABTS radical solution was diluted in $50 \mathrm{ml}$ of absolute ethanol. And then $50 \mu \mathrm{l}$ of sample stock $(1 \mathrm{mg} / \mathrm{ml})$ was added to $1 \mathrm{ml}$ of ABTS radical solution. After incubation at room temperature for $20 \mathrm{~min}$, Absorbance value was measured at $734 \mathrm{~nm}$. The ABTS radical-scavenging activity $(\%)=($ Absorbance of control - Absorbance of sample $) \times 100 /$ (Absorbance of control). The $\mathrm{EC}_{50}$ values denote the effective concentration of sample that is required to scavenge $50 \%$ of the ABTS free radicals [30]. All determinations were conducted in triplicates.

\section{Ferric thiocyanate (FTC) assay}

The FTC method was performed as previously described [31]. Briefly, a mixture of $1.2 \mathrm{ml}$ of sample $(1 \mathrm{mg} / \mathrm{ml}$ in DMSO), $1.2 \mathrm{ml}$ of linoleic acid ( $25 \mathrm{mg} / \mathrm{ml}$ in $\mathrm{EtOH}), 2.4 \mathrm{ml}$ of $0.2 \mathrm{M}$ phosphate buffer ( $\mathrm{pH} 7.0$ ), and $1.2 \mathrm{ml}$ of distilled water was placed at $40^{\circ} \mathrm{C}$ in the dark for indicated time periods. Twenty five microliters of the mixture were mixed with $25 \mu \mathrm{l}$ of ammonium thiocyanate $\left(0.3 \mu \mathrm{g} / \mathrm{ml}\right.$ in $\left.\mathrm{H}_{2} \mathrm{O}\right)$, $25 \mu \mathrm{l}$ of ferrous chloride $(2.45 \mathrm{mg} / \mathrm{ml}$ in $3.5 \%$ hydrochloric acid), and $750 \mu \mathrm{l}$ of $70 \% \mathrm{EtOH}$, and then incubated for 3 $\mathrm{min}$. The optical density (OD) of the reaction of mixture was measured at $500 \mathrm{~nm}$. A mixture without added sample was used as a negative control. The percent of inhibition of lipid peroxidation $=100-\left(\mathrm{A}_{1}-\mathrm{A}_{0}\right) \times 100$, where $\mathrm{A}_{0}$ is the absorbance of the negative control and $A_{1}$ is the absorbance of the extract samples [8]. The experiment was performed in triplicates.

\section{Thiobarbituric acid (TBA) assay}

The TBA assay was performed as described elsewhere [37]. Briefly, $300 \mu \mathrm{l}$ of $20 \%$ trichloroacetic acid (TCA) and $150 \mu \mathrm{l}$ of $0.67 \%$ thiobarbituric acid (TBA) were added to 300 $\mu \mathrm{l}$ of sample solution or standard solution. The mixture was placed in a boiling water bath for $10 \mathrm{~min}$. After cooling, the mixture was centrifuged at 3,000 rpm for $20 \mathrm{~min}$. Absorbance of supernatant was measured at $532 \mathrm{~nm}$. The percentage of inhibition of lipid peroxidation $=($ Absorbance of con- 
trol - Absorbance of sample) $\times 100 /$ Absorbance of control. The experiment was performed in triplicates.

\section{Flow cytometric analysis}

Flow cytometric analysis for the cell cycle of HL-60 cells was carried out as previously described [46]. Changes in the $\Delta \psi_{\mathrm{m}}$ were measured after staining with 3,3'-dihexyloxacarbocyanine iodide $\left(\mathrm{DiOC}_{6}\right)$ [19]. The cells were harvested and incubated with PBS containing $50 \mathrm{nM} \mathrm{DiOC} 6$ for $15 \mathrm{~min}$ at $37^{\circ} \mathrm{C}$ prior to flow cytometric analysis.

The cytoprotective effect of the $80 \%$ ethanol extracts and their ethyl acetate fractions obtained from hwanggeumchal sorghum, glutinous sorghum, and barnyard millet grains against tertiary-butyl hydroperoxide (TBHP)-induced cytotoxicity in HL-60 cells was also measured by flow cytometry. Briefly, the cells $\left(0.5 \times 10^{6} / \mathrm{ml}\right)$ were preincubated with a proper dilution of individual samples for $1 \mathrm{~h}$, and then exposed to $100 \mu \mathrm{M}$ TBHP for indicated time periods. After the cells were harvested, equivalent number of cells were fixed with cold ethanol $(67 \%)$, stained with propidium iodide, and subjected to flow cytometric analysis to quantify apoptotic sub-G $\mathrm{G}_{1}$ cells. Following flow cytometric analysis for apoptotic sub-G $\mathrm{G}_{1}$ cells, the protective activity against TBHP-induced apoptosis was determined according to the equation: Cytoprotection ratio $(\%)=\left(\right.$ sub- $\mathrm{G}_{1}$ cell ratio for $100 \mu \mathrm{M}$ TBHP - sub-G $G_{1}$ cell ratio for $100 \mu \mathrm{M}$ TBHP plus sample) $\times 100 /$ sub-G ${ }_{1}$ cell ratio for $100 \mu \mathrm{M}$ TBHP.

\section{Quantification of total phenolic compounds}

Total phenolic contents in the $80 \%$ ethanol extracts and organic solvent fractions of selected miscellaneous cereal grains were measured by Folin-Ciocalteau method using tannic acid as a standard phenolic compound as previously described [39]. The 80\% EtOH extracts and organic solvent fractions were split $100 \mu \mathrm{l}$ to each test tubes, then $500 \mu \mathrm{l}$ of Folin-Ciocalteau reagent was added. The mixture was incubated at RT for $5 \mathrm{~min}$ and added $400 \mu \mathrm{l} 7.5 \% \mathrm{Na}_{2} \mathrm{CO}_{3}$. This mixture was incubated at $50^{\circ} \mathrm{C}$ for $5 \mathrm{~min}$, and centrifuged at $13,000 \mathrm{rpm}$ for $2 \mathrm{~min}$ to remove insoluble precipitation. The absorbance was then measured at $760 \mathrm{~nm}$. Total phenolic content was indicated in $\mu \mathrm{g}$ of tannic acid (TAE) equivalents per milligram of extract ( $\mu \mathrm{T} \mathrm{TAE} / \mathrm{mg}$ extract). All determinations were conducted in triplicates.

Preparation of cell lysates and Western blot analysis

Cellular lysates were prepared by suspending HL-60 cells $\left(5 \times 10^{6}\right.$ cells $)$ in $250 \mu \mathrm{l}$ of lysis buffer $(137 \mathrm{mM} \mathrm{NaCl}, 15 \mathrm{mM}$ EGTA, $1 \mathrm{mM}$ sodium orthovanadate, $15 \mathrm{mM} \mathrm{MgCl}_{2}, 0.1 \%$ Triton X-100, $25 \mathrm{mM}$ MOPS, and $5.0 \mu \mathrm{g} / \mathrm{ml}$ proteinase inhibitor E-64, pH 7.2). The cells were disrupted by sonication and extracted at $4^{\circ} \mathrm{C}$ for $30 \mathrm{~min}$. An equivalent amount of protein lysate $(20 \sim 25 \mathrm{\mu g})$ was electrophoresed on a $4-12 \%$ NuPAGE gradient gel (Invitrogen/Novex, Carlsbad, CA, USA) with MOPS buffer, and then electrotransferred to Immobilon-P membranes. Detection of individual proteins was performed using an ECL Western blotting kit according to the manufacturer's instructions.

\section{Statistical analysis}

Unless otherwise indicated, each result in this paper is representative of at least three separate experiments. Values represent the mean \pm standard deviation (SD) of these experiments. The statistical significance was calculated with Student's $t$-test. $P$ values less than 0.05 were considered significant.

\section{Results and Discussion}

DPPH radical- and ABTS radical-scavenging activities of the $80 \%$ ethanol extracts and their solvent fractions obtained from eleven selected miscellaneous cereal grains

To evaluate antioxidant properties of miscellaneous cereal grains, which were harvested in Korea, including proso millet, yellow glutinous proso millet, hwanggeumchal sorghum, glutinous sorghum, white glutinous sorghum, yellow glutinous foxtail millet, non-glutinous foxtail millet, green glutinous foxtail millet, golden foxtail millet, barnyard millet and adlay, the free radical-scavenging activities of $80 \%$ ethanol extracts prepared from the individual grains were measured using DPPH and ABTS methods, both of which have widely been employed to evaluate free radical-scavenging activities of natural compounds in foods and biological systems [34, 43]. As shown in Table 1, the $80 \%$ ethanol extract of hwanggeumchal sorghum grains exhibited the highest DPPH radical-scavenging activity followed by those of glutinous sorghum and barnyard millet grains. The $\mathrm{EC}_{50}$ values of the $80 \%$ ethanol extracts of hwanggeumchal sorghum, glutinous sorghum, and barnyard millet grains for DPPH radical-scavenging activity appeared to be 33.82, 131.10 and $141.70 \mu \mathrm{g} /$ $\mathrm{ml}$, respectively. The ABTS radical-scavenging activity assay also showed that the $80 \%$ ethanol extract of hwanggeumchal 
Table 1. EC 50 values of the $80 \%$ ethanol extracts of eleven miscellaneous cereal grains for DPPH and ABTS radical-scavenging activity

\begin{tabular}{lcc}
\hline \multirow{2}{*}{ Miscellaneous cereal grains } & \multicolumn{2}{c}{$80 \%$ EtOH extract } \\
\cline { 2 - 3 } & $\begin{array}{c}\text { DPPH EC } \\
(\mu \mathrm{g} / \mathrm{ml})\end{array}$ & $\begin{array}{c}\mathrm{ABTS} \mathrm{EC}_{50} \\
(\mu \mathrm{g} / \mathrm{ml})\end{array}$ \\
\hline Proso millet & $>235.3$ & $>190.5$ \\
Yellow proso millet & $>235.3$ & $175.30 \pm 1.50$ \\
Hwanggeumchal sorghum & $33.82 \pm 0.06$ & $8.41 \pm 0.88$ \\
Glutinous sorghum & $131.10 \pm 0.20$ & $29.59 \pm 0.02$ \\
White glutinous sorghum & $>235.3$ & $105.90 \pm 0.60$ \\
Yellow glutinous foxtail millet & $>235.3$ & $161.50 \pm 1.50$ \\
Non-glutinous foxtail millet & $>235.3$ & $>190.5$ \\
Green glutinous foxtail millet & $>235.3$ & $95.00 \pm 3.00$ \\
Golden foxtail millet & $>235.3$ & $134.70 \pm 1.40$ \\
Barnyard millet & $141.70 \pm 0.60$ & $25.95 \pm 0.75$ \\
Adlay & $>235.3$ & $>190.5$ \\
a-tocopherol & 19.84 & 9.81 \\
\hline
\end{tabular}

sorghum grains had the highest ABTS radical-scavenging activity followed by those of barnyard millet and glutinous sorghum grains. The $\mathrm{EC}_{50}$ values of the ethanol extracts of hwanggeumchal sorghum, glutinous sorghum, and barnyard millet grains for ABTS radical-scavenging activity were $8.41,25.95$ and $29.59 \mu \mathrm{g} / \mathrm{ml}$, respectively.

In order to examine further the antioxidant properties of hwanggeumchal sorghum, glutinous sorghum, and barn- yard millet grains, the $80 \%$ ethanol extracts of the three miscellaneous cereal grains were sequentially fractionated with n-hexane, methylene chloride, ethyl acetate and n-butanol, and th

en individual organic solvent fractions were tested for the DPPH and ABTS radical scavenging activities. As shown in Table 2, the ethyl acetate and butanol fractions exhibited more potent DPPH radical- and ABTS radical-scavenging activities as compared to other organic solvent fractions of hwanggeumchal sorghum, glutinous sorghum, and barnyard millet. The $\mathrm{EC}_{50}$ values of the ethyl acetate fractions of hwanggeumchal sorghum, glutinous sorghum, and barnyard millet grains were 12.65, 16.03 and $31.41 \mu \mathrm{g} / \mathrm{ml}$ for DPPH radical-scavenging activity, and 4.52, 8.31 and 11.10 $\mu \mathrm{g} / \mathrm{ml}$ for ABTS radical-scavenging activity. In addition, the $\mathrm{EC}_{50}$ values of the butanol fractions of hwanggeumchal sorghum, glutinous sorghum, and barnyard millet grains were 14.65, 27.91 and $39.59 \mu \mathrm{g} / \mathrm{ml}$ for DPPH radical-scavenging activities, and 5.48, 9.12 and $16.46 \mu \mathrm{g} / \mathrm{ml}$ for ABTS radical-scavenging activities. On the other hands, the $\mathrm{EC}_{50}$ values of a-tocopherol, which is a well-known natural antioxidant [16], for DPPH radical- and ABTS radical-scavenging activities were 19.84 and $9.81 \mathrm{\mu g} / \mathrm{ml}$, respectively.

Consequently, these results showed that the ethyl acetate fraction of glutinous sorghum grains as well as both the eth-

Table 2. $\mathrm{EC}_{50}$ values of the $80 \%$ ethanol extracts and their organic solvent fractions of glutinous sorghum, hwanggeumchal sorghum, and barnyard millet for DPPH and ABTS radical-scavenging activity

\begin{tabular}{|c|c|c|c|}
\hline \multicolumn{2}{|c|}{ Sample } & DPPH EC $50(\mu \mathrm{g} / \mathrm{ml})$ & ABTS $\mathrm{EC}_{50}(\mu \mathrm{g} / \mathrm{ml})$ \\
\hline \multirow{6}{*}{ Hwanggeumchal sorghum } & $\mathrm{EtOH}$ & $33.82 \pm 0.06$ & $8.41 \pm 0.88$ \\
\hline & Hexane & $55.41 \pm 1.00$ & $27.45 \pm 1.35$ \\
\hline & $\mathrm{MC}$ & $>58.82$ & $31.67 \pm 0.19$ \\
\hline & EtOAc & $12.65 \pm 0.01$ & $4.52 \pm 0.05$ \\
\hline & $\mathrm{BuOH}$ & $14.65 \pm 0.06$ & $5.48 \pm 0.05$ \\
\hline & $\mathrm{H}_{2} \mathrm{O}$ & $48.50 \pm 0.26$ & $21.45 \pm 0.07$ \\
\hline \multirow{6}{*}{ Glutinous sorghum } & $\mathrm{EtOH}$ & $131.10 \pm 0.20$ & $29.59 \pm 0.02$ \\
\hline & Hexane & $>58.82$ & $>47.62$ \\
\hline & $\mathrm{MC}$ & $>58.82$ & $>47.62$ \\
\hline & EtOAc & $16.03 \pm 0.03$ & $8.31 \pm 0.06$ \\
\hline & $\mathrm{BuOH}$ & $27.91 \pm 0.09$ & $9.12 \pm 0.12$ \\
\hline & $\mathrm{H}_{2} \mathrm{O}$ & $>58.82$ & $>47.62$ \\
\hline \multirow{7}{*}{ Barnyard millet } & $\mathrm{EtOH}$ & $141.70 \pm 0.60$ & $25.95 \pm 0.75$ \\
\hline & Hexane & $>58.82$ & $>47.62$ \\
\hline & $\mathrm{MC}$ & $>58.82$ & $17.29 \pm 0.15$ \\
\hline & EtOAc & $31.41 \pm 0.06$ & $11.10 \pm 0.24$ \\
\hline & $\mathrm{BuOH}$ & $39.59 \pm 0.35$ & $16.46 \pm 0.16$ \\
\hline & $\mathrm{H}_{2} \mathrm{O}$ & $>58.82$ & $44.29 \pm 0.15$ \\
\hline & a-tocopherol & 19.84 & 9.81 \\
\hline
\end{tabular}


yl acetate and butanol fractions of hwanggeumchal sorghum grains possessed higher DPPH radical- and ABTS radical-scavenging activities than those of a-tocopherol. In addition, these results raised the possibility that the free-radical scavenging activity-related component(s) in the ethyl acetate fraction of glutinous sorghum grains, and the ethyl acetate and butanol fractions of hwanggeumchal sorghum grains might have more potent antioxidant activity than a-tocopherol.

Inhibitory effect of the $80 \%$ ethanol extracts, ethyl acetate fractions, and butanol fractions from hwanggeumchal sorghum, glutinous sorghum and barnyard millet grains on linoleic acid peroxidation

Lipids undergo oxidative degradation (lipid peroxidation) in the presence of reactive oxygen species (ROS) [30]. As a basic mechanism underlying lipid peroxidation, ROS are known to abstract a hydrogen atom from a methylene group of unsaturated fatty acids, such as linoleic acid, linolenic acid and arachidonic acid, and subsequently form free radicals such as peroxyl radicals. Once the free radicals are formed, lipid peroxidation progresses to produce various secondary oxidation products. Ferric thiocyanate (FTC) assay and thiobarbituric acid (TBA) assay, which are frequently used as antioxidant tests for plant and food components, are known to specifically monitor hydroperoxide and malonaldehyde (MA) as the products of lipid peroxidation, respectively. In order to examine whether the antioxidant properties of glutinous sorghum, hwanggeumchal sorghum and barnyard millet grains, which were detectable by DPPH radical- and ABTS radical-scavenging activities, could also prevent lipid peroxidation, we decided to investigate the effects of the $80 \%$ ethanol extracts, ethyl acetate fractions, and butanol fractions from hwanggeumchal sorghum, glutinous sorghum and barnyard millet grains on linoleic acid peroxidation by employing both FTC and TBA methods.

In FTC assay, the amount of linoleic acid peroxidation is determined by measuring ferrous oxidation to ferric iron, because the oxidized linoleic acid reacts with ferrous to form ferric ion which then reacts with ammonium thiocyanate to generate ferric thiocyanate possessing red color [30]. As shown in Fig. 1A, the absorbance values of the FTC reaction mixture containing linoleic acid solutions which were obtained after treatment for the indicated time periods appeared to increase in a time-dependent manner and exhibited 3.5-fold elevation after linoleic acid solution was treated at $40^{\circ} \mathrm{C}$ for 5 days. This indicated a continuous enhancement in linoleic acid peroxidation during the 5-day treatment. However, the linoleic acid solution treated in the presence of the individual organic solvent fractions of hwanggeumchal sorghum, glutinous sorghum and barnyard millet grains, failed to elevate the absorbance value of the reaction mixtures with the percentage inhibition of $86 \%-91 \%$. These inhibitory effects of hwanggeumchal sorghum, glutinous sorghum and barnyard millet grains, which lowered the absorbance values of the FTC reaction mixture, were comparable to those of a-tocopherol. These results showed that antioxidant properties of the organic solvent fractions of glutinous sorghum, hwanggeumchal sorghum, and barnyard millet grains could commonly inhibit linoleic acid peroxidation. In TBA assay, the level of malonaldehyde (MA) among lipid peroxidation products is measured to evaluate the antioxidant activity of chemical(s) in linoleic acid peroxidation system, because MA is known to bind TBA to form a red compound MA-TBA adduct. When the TBA reaction mixtures containing the linoleic acid sample prepared in the FTC method was tested, a similar trend was observed with all tested extracts exhibiting low absorbance values corresponding to the percentage inhibition of $38.0-56.1 \%$ (Fig. 1B). Under the same conditions, the controls, a-tocopherol showed a slightly lower inhibition of $48.5 \%$, when compared with the inhibition values observed in the FTC assay. These results showed that the data of the TBA assay correlated well with those of the FTC assay. Consequently, current data demonstrated that glutinous sorghum, hwanggeumchal sorghum and barnyard millet grains commonly possessed the antioxidant properties which could inhibit ROS-mediated lipid peroxidation.

Quantification of phenolic compounds in the $80 \%$ ethanol extracts and organic solvent fractions

Phenolic compounds are known as very important antioxidant constituents of plants and their radical scavenging ability is due to their redox properties, hydrogen donors, free radical quenchers and metal-chelators [15]. Previously many studies have demonstrated a high correlation between the contents of total phenolic compounds in plants and their antioxidant capacity $[7,18,33,35,47]$. To investigate the correlation between antioxidant activities and total phenolic contents, the ethanol extracts and their organic solvent fractions were analyzed for total phenolic contents using Folin-Ciocalteau method. 


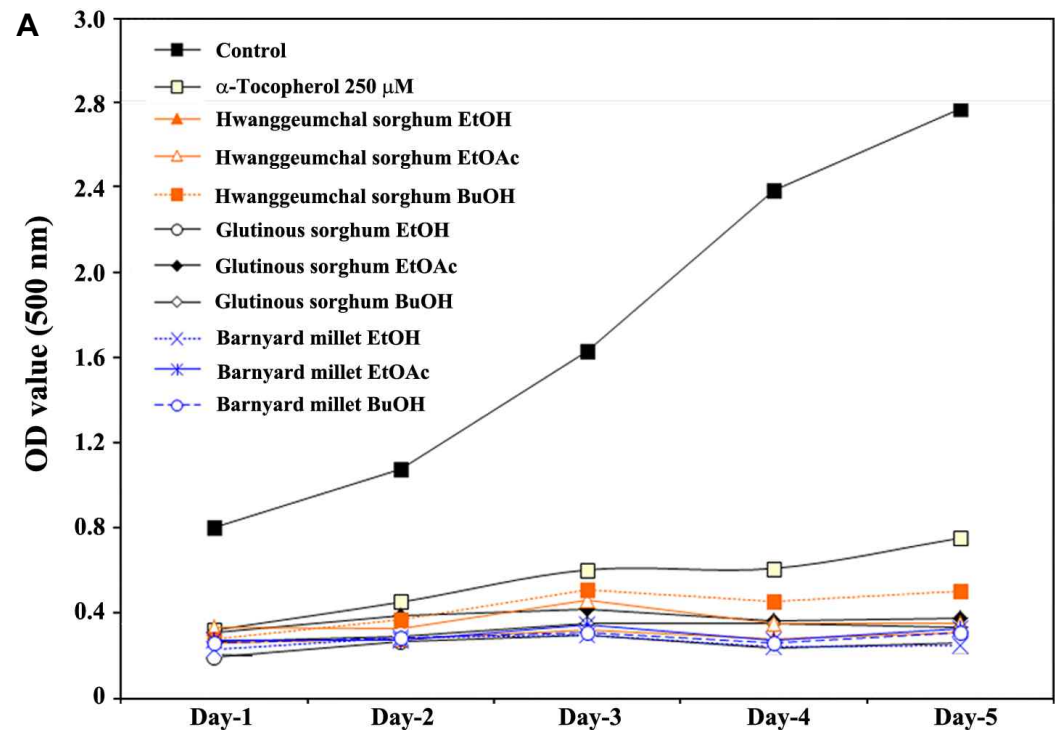

B

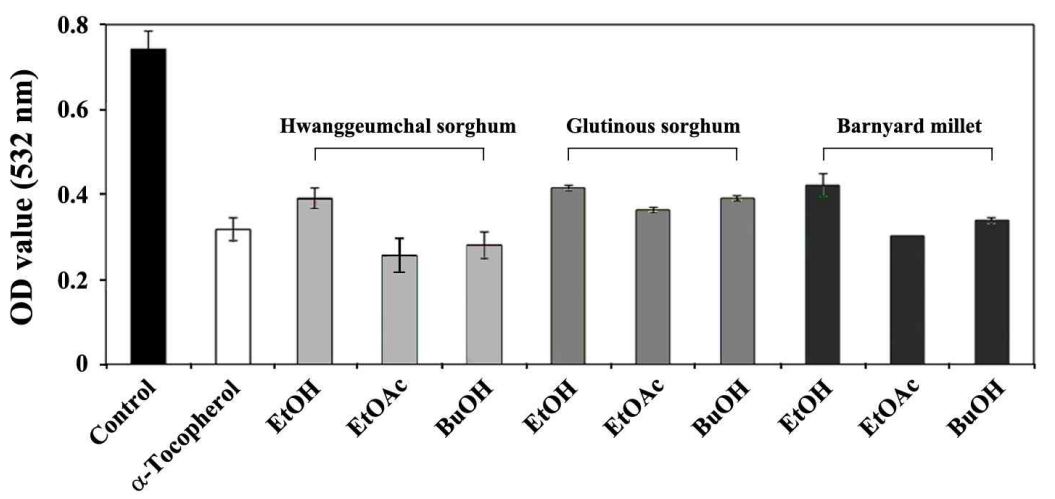

Fig. 1. Evaluation of lipid peroxidation inhibitory activity of the $80 \% \mathrm{EtOH}$ extracts, and their ethyl acetate and butanol fractions of hwanggeumchal sorghum, glutinous sorghum, and barnyard millet grains by ferric thiocyanate (FTC) method (A) and thiobarbituric acid (TBA) method (B). The experiment was performed in triplicates. Results are expressed as mean \pm standard error of the mean $(n=3)$.
The concentrations of phenolic compounds in the individual extracts expressed as $\mu \mathrm{g}$ of tannic acid (TAE) equivalents per mg of the extract ( $\mu \mathrm{g} \mathrm{TAE} / \mathrm{mg}$ extract) are shown in Table 3. The $80 \%$ ethanol extracts of hwanggeumchal sorghum, glutinous sorghum and barnyard millet grains appeared to contain higher level of total phenolic compounds than other ethanol extracts tested, with exhibiting $121.1 \mathrm{\mu g}$ $\mathrm{TAE} / \mathrm{mg}$, $55.0 \mu \mathrm{g} \mathrm{TAE} / \mathrm{mg}$, and $66.8 \mu \mathrm{g} \mathrm{TAE} / \mathrm{mg}$, respectively. When the phenolic contents in the individual organic solvent fractions of hwanggeumchal sorghum, glutinous sorghum, and barnyard millet grains were compared, most phenolic components of hwanggeumchal sorghum, glutinous sorghum, and barnyard millet grains were distributed in both ethyl acetate and butanol fractions. The contents of phenolic compounds in the ethyl acetate and butanol fractions of hwanggeumchal sorghum grains were $255.2 \mu \mathrm{g}$ $\mathrm{TAE} / \mathrm{mg}$ and $244.1 \mathrm{\mu g} \mathrm{TAE} / \mathrm{mg}$, whereas the phenolic contents in the ethyl acetate and butanol fractions of glutinous sorghum grains were $248.4 \mu \mathrm{g}$ TAE/mg and $159.5 \mu \mathrm{g}$ TAE/ $\mathrm{mg}$, respectively. At the same time, the phenolic contents in the ethyl acetate and butanol fractions of barnyard millet were $198.7 \mu \mathrm{g}$ TAE/mg and $137.9 \mu \mathrm{g}$ TAE/mg, respectively. These quantitative levels of total phenolic compounds appeared to be consistent with the antioxidant activity profiles measured in this study. Consequently, current results suggested that the antioxidant activities of the hwanggeumchal sorghum, glutinous sorghum and barnyard millet grains were mainly attributable to the presence of phenolic components.

Inhibitory effect of the ethyl acetate fractions of
hwanggeumchal sorghum, glutinous sorghum, and
barnyard millet grains on TBHP-induced apoptotic sig-
naling and cell death in human $\mathrm{HL}-60$ cells

Since the ethyl acetate fractions of hwanggeumchal sorghum, glutinous sorghum and barnyard millet grains exhibited higher level of DPPH radical- and ABTS radical-scavenging activities and phenolic ingredients than those of the 
Table 3. Total phenolic contents in the $80 \%$ ethanol extracts of individual miscellaneous cereal grains, and their organic solvent fractions from the grains of glutinous sorghum, hwanggeumchal sorghum, and barnyard millet

\begin{tabular}{|c|c|c|c|c|}
\hline $\begin{array}{l}\text { Miscellaneous cereal grains } \\
(80 \% \text { EtOH extract })\end{array}$ & $\begin{array}{c}\text { Total phenolic contents } \\
(\mu \mathrm{g} / \mathrm{mg})^{*}\end{array}$ & Sample & & $\begin{array}{c}\text { Total phenolic contents } \\
(\mu \mathrm{g} / \mathrm{mg})^{*}\end{array}$ \\
\hline Proso millet & 2.5 & \multirow{5}{*}{$\begin{array}{l}\text { Hwang-geumchal } \\
\text { sorghum }\end{array}$} & Hexane & 56.2 \\
\hline Yellow proso millet & 7.6 & & $\mathrm{MC}$ & 60.1 \\
\hline Hwanggeumchal sorghum & 121.1 & & EtOAc & 255.2 \\
\hline Glutinous sorghum & 55.0 & & $\mathrm{BuOH}$ & 244.1 \\
\hline White glutinous sorghum & 16.5 & & $\mathrm{H}_{2} \mathrm{O}$ & 10.9 \\
\hline $\begin{array}{l}\text { Yellow glutinous foxtail millet } \\
\text { Non-glutinous foxtail millet }\end{array}$ & $\begin{array}{l}4.8 \\
1.8\end{array}$ & \multirow{5}{*}{ Glutinous sorghum } & Hexane & 7.6 \\
\hline Green glutinous foxtail millet & 4.0 & & $\mathrm{MC}$ & 14.6 \\
\hline Golden foxtail millet & 8.9 & & EtOAc & 248.4 \\
\hline Barnyard millet & 66.8 & & $\mathrm{BuOH}$ & 159.5 \\
\hline \multirow[t]{6}{*}{ Adlay } & 5.7 & & $\mathrm{H}_{2} \mathrm{O}$ & 32.0 \\
\hline & & \multirow{5}{*}{ Barnyard millet } & Hexane & 81.7 \\
\hline & & & $\mathrm{MC}$ & 117.8 \\
\hline & & & EtOAc & 198.7 \\
\hline & & & $\mathrm{BuOH}$ & 137.9 \\
\hline & & & $\mathrm{H}_{2} \mathrm{O}$ & 34.9 \\
\hline
\end{tabular}

*The concentrations of phenolic compounds in the individual extracts were expressed as $\mu \mathrm{g}$ of tannic acid (TAE) equivalents per $\mathrm{mg}$ of the extract ( $\mu \mathrm{g} \mathrm{TAE} / \mathrm{mg}$ extract).

other organic solvent fractions, we decided to examine whether the ethyl acetate fractions could prevent the oxidative stress-mediated apoptotic cell death in human cells. In this context, the effect of the ethyl acetate fractions on TBHP-induced apoptotic sub-G $\mathrm{G}_{1}$ peak at concentrations of 12.5 and $25 \mu \mathrm{g} / \mathrm{ml}$ in human HL-60 cells was analyzed by flow cytometry. Previously, it has been reported that TBHP is a potent free radical generating toxin to mimic the oxidative stress and thus can provoke oxidative stress-mediated apoptotic cell death [1, 14].

As shown in Fig. 2, the ethyl acetate fractions of hwanggeumchal sorghum, glutinous sorghum and barnyard millet grains at a concentration of $25 \mu \mathrm{g} / \mathrm{ml}$ could inhibit the TBHP-induced sub-G $\mathrm{G}_{1}$ peak to the levels of $51.9 \%, 65.9 \%$, and $72.2 \%$, respectively. At the same time, the ethyl acetate fractions at a concentration of $12.5 \mu \mathrm{g} / \mathrm{ml}$ could inhibit the TBHP-induced sub-G $\mathrm{G}_{1}$ peak to the levels of $25.4 \%, 48.5 \%$, and $31.1 \%$, respectively. The $80 \%$ EtOH extracts $(25 \mu \mathrm{g} / \mathrm{ml}$ and $50 \mu \mathrm{g} / \mathrm{ml}$ ) of hwanggeumchal sorghum and glutinous sorghum grains appeared to reduce the TBHP-induced sub-G peak slightly with the percentage inhibition of $<10 \%$, whereas the $80 \% \mathrm{EtOH}$ extract of barnyard millet grains at the same dose failed to reduce the level of TBHP-induced apoptotic sub-G $\mathrm{G}_{1}$ peak. In addition, the control a-tocopherol $(100 \mu \mathrm{M})$ was able to inhibit the TBHP-induced sub-G peak to the level of $23.7 \%$. It is noteworthy that the presence of a-tocopherol at concentrations of $>100 \mu \mathrm{M}$ appeared to exert cytotoxicity toward HL-60 cells. Consequently, these results demonstrated that the cytoprotective effect of the ethyl acetate fractions of hwanggeumchal sorghum, glutinous sorghum and barnyard millet grains on TBHP-induced apoptosis was exerted in a dose-dependent manner. These results also suggested that the cytoprotection of the ethyl acetate fractions against oxidative damage might be more potent than that of a-tocopherol.

To elucidate the biochemical mechanism underlying the cytoprotective effect of the ethyl acetate fractions of hwanggeumchal sorghum, glutinous sorghum, and barnyard millet grains on the TBHP-induced apoptosis, we investigate the effect of the ethyl acetate extracts on the TBHP-induced apoptotic signaling pathway using flow cytometry and western blot analyses. After HL-60 cells were treated with the individual ethyl acetate fractions $(25 \mu \mathrm{g} / \mathrm{ml})$ for $1 \mathrm{~h}$, the cells were exposed to $100 \mu \mathrm{M}$ TBHP for $5 \mathrm{~h}$. As shown in Fig. $3 \mathrm{~A}$, although HL-60 cells following treatment with TBHP exhibited $65.5 \%$ of apoptotic sub- $\mathrm{G}_{1}$ cells, the sub- $\mathrm{G}_{1}$ cells declined to the levels of $35.0 \%, 28.2 \%$, and $30.9 \%$ in the presence of the ethyl acetate fractions of hwanggeumchal sorghum, glutinous sorghum, and barnyard millet grains, respectively, indicating a significant reduction in the level of TBHP-induced apoptotic cell death by the ethyl acetate fractions. Under these conditions, the effect of the ethyl ace- 

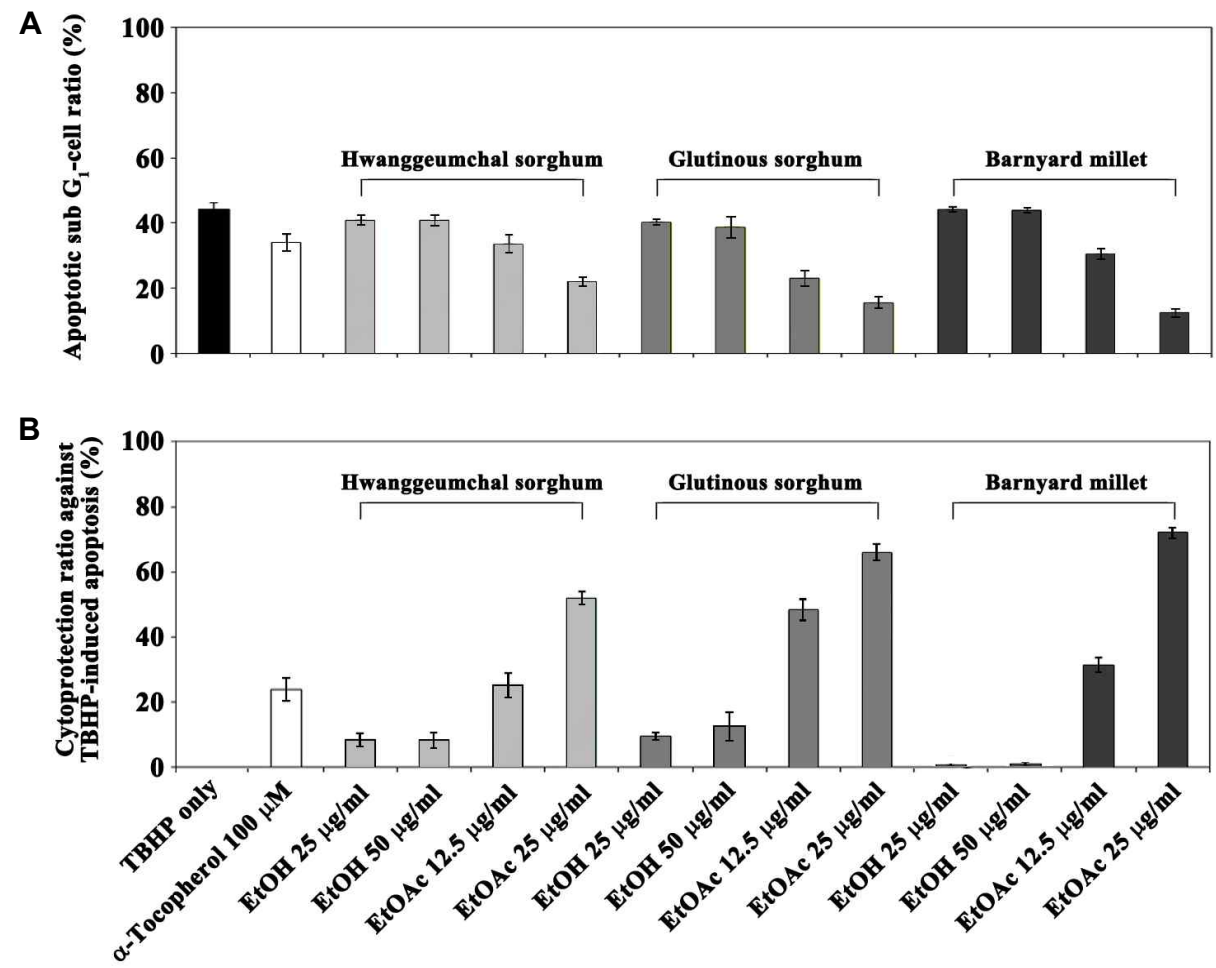

Fig. 2. Cytoprotective effect of the $80 \%$ EtOH extracts and ethyl acetate fractions of hwanggeumchal sorghum, glutinous sorghum, and barnyard millet grains on tertiary-butyl hydroperoxide (TBHP)-induced apoptotic cell death (sub-G $\mathrm{G}_{1}$ peak) in human HL-60 cells. The cells were incubated at a density of $5 \times 10^{5} / \mathrm{ml}$ with the indicated concentrations of the $80 \%$ EtOH extracts and their ethyl acetate fractions for $5 \mathrm{~h}$. Flow cytometric analysis of the cell cycle distribution was performed as described in Materials and Methods. The experiment was performed in triplicates. Results are expressed as mean \pm standard error of the mean $(n=3)$.

tate fractions on TBHP-induced mitochondrial membrane potential $(\Delta \psi \mathrm{m})$ loss was also measured by flow cytometry using $\mathrm{DiOC}_{6}$ staining. Although there was barely detectable $\Delta \psi \mathrm{m}$ loss in continuously growing HL-60 cells, $58.3 \%$ cells exhibited $\Delta \psi \mathrm{m}$ loss following exposed to TBHP (Fig. 3B). However, the presence of the ethyl acetate fractions of hwanggeumchal sorghum, glutinous sorghum, and barnyard millet grains could reduce the TBHP-induced $\Delta \psi \mathrm{m}$ loss to the levels of $35.7 \%, 29.8 \%$, and $36.8 \%$, respectively. This indicated that the oxidative stress-mediated mitochondrial damage in HL-60 cells treated with TBHP could be protected by the ethyl acetate fractions of hwanggeumchal sorghum, glutinous sorghum, and barnyard millet grains. The control a-tocopherol $(100 \mu \mathrm{M})$ appeared to reduce the TBHP-induced $\Delta \psi m$ loss to the level of $42.4 \%$. Because $\Delta \psi \mathrm{m}$ loss is known to be one of the initial intracellular changes that are accompanied by apoptotic cell death [42], these results suggested that $\Delta \psi \mathrm{m}$ loss being involved in TBHP-induced apoptosis was prevented by the ethyl acetate fractions of hwanggeumchal sorghum, glutinous sorghum, and barn- yard millet grains. These results indicated that the ethyl acetate fractions of hwanggeumchal sorghum, glutinous sorghum, and barnyard millet grains could suppress the oxidative stress-mediated $\Delta \psi m$ loss more efficiently than the antioxidant control, a-tocopherol.

Since it was reported that $\Delta \psi_{\mathrm{m}}$ loss precedes the release of cytochrome $c$ into the cytosol, followed by caspase cascade activation [24, 41], it was likely that the suppression of TBHP-induced $\Delta \psi_{\mathrm{m}}$ loss by the ethyl acetate fractions might be reflected by a reduction in mitochondria-dependent activation of caspase- 9 and -3 , leading to degradation of PARP and lamin B, in HL-60 cells. To test this prediction, it was investigated in HL-60 cells, by western blot analysis, whether TBHP-induced activation of caspase- 9 and -3 could be suppressed by pretreatment with the ethyl acetate fractions. In accordance with the $\Delta \psi_{\mathrm{m}}$ loss, the cleavage of procaspase-9 $(47 \mathrm{kDa})$ to active forms $(37 / 35 \mathrm{kDa})$ as well as the cleavage of procaspase-3 (32 kDa) into active form (17 kDa) was detected in HL-60 cells treated with TBHP (Fig. 4). At the same time, the degradation of PARP and lamin 
A

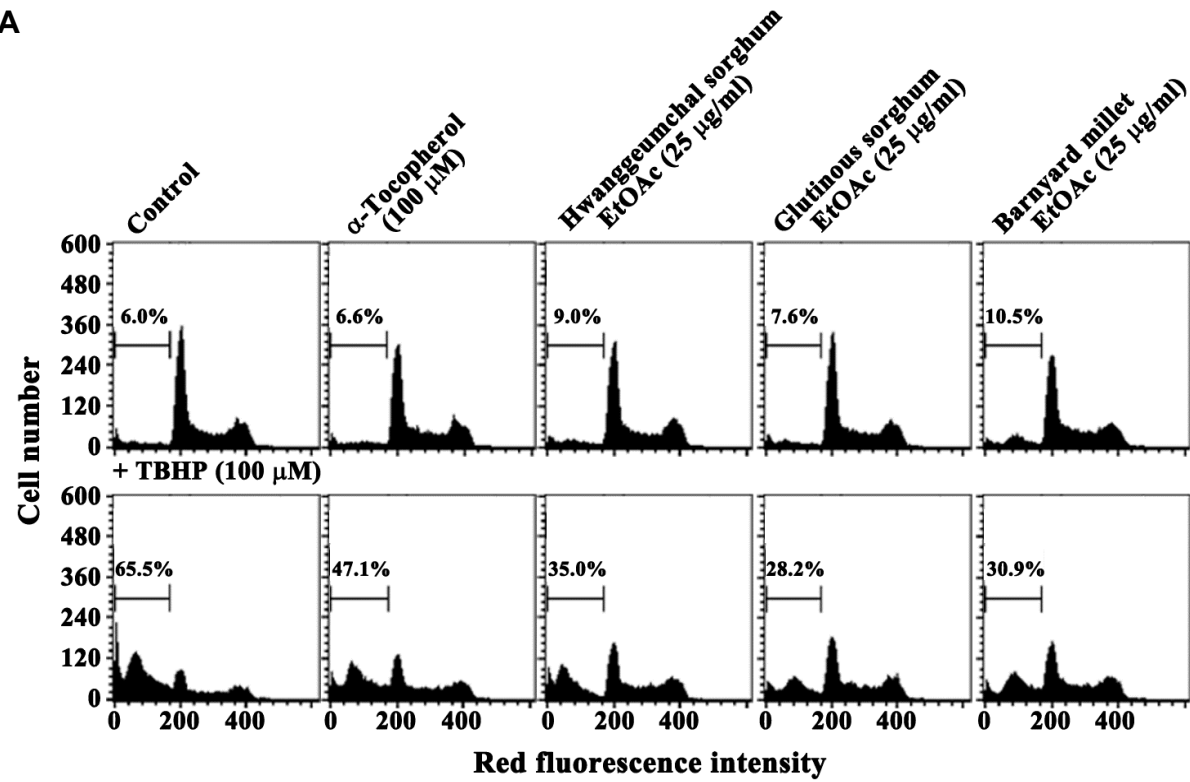

B

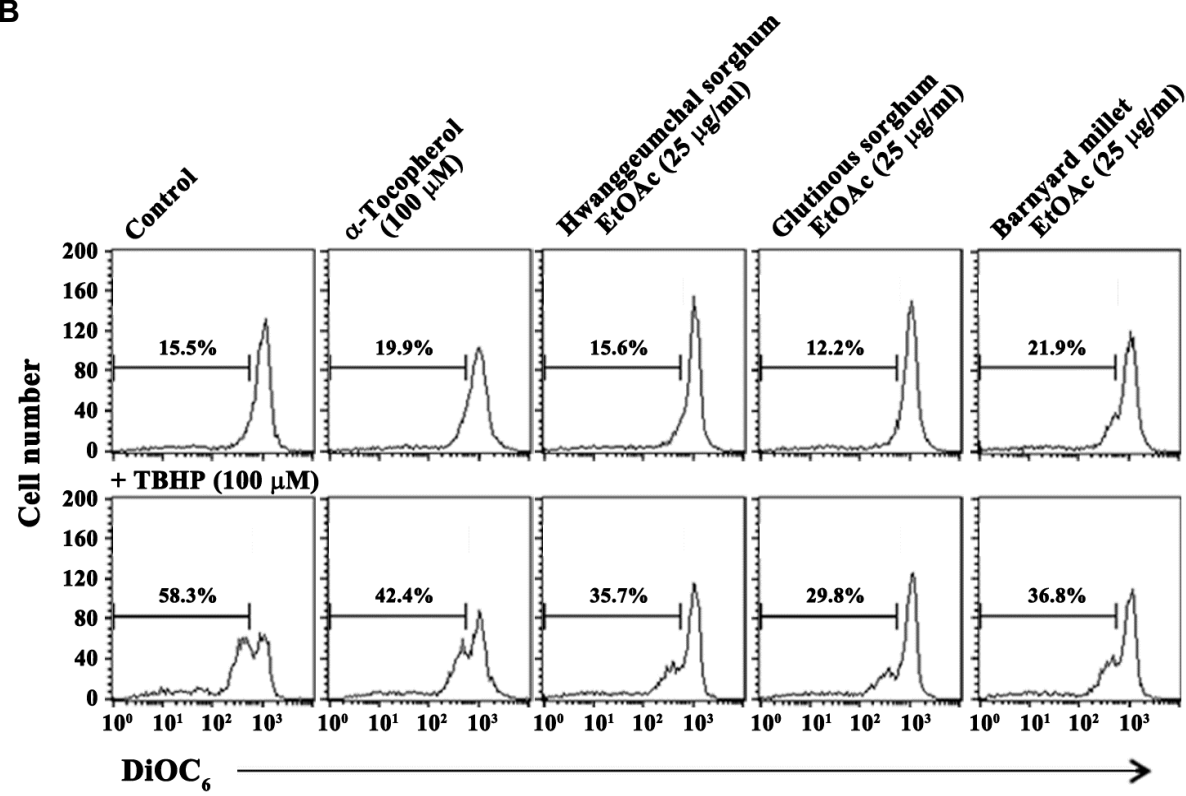

Fig. 3. Cytoprotective effect of the ethyl acetate fractions of hwanggeumchal sorghum, glutinous sorghum, and barnyard millet grains on TBHP $(100 \mu \mathrm{M})$-induced apoptotic cell death (sub-G $\mathrm{G}_{1}$ peak) (A) and mitochondria membrane potential $\left(\Delta \psi_{\mathrm{m}}\right)$ loss (B) in human HL-60 cells. The cells were incubated at a density of $5 \times 10^{5} / \mathrm{ml}$ with the indicated concentrations of the ethyl acetate fractions for $5 \mathrm{~h}$. Flow cytometric analysis of the cell cycle distribution and $\Delta \psi_{\mathrm{m}}$ loss was performed as described in Materials and Methods. A representative study is shown and two additional experiments yielded similar results.

B was detected along with the activation of caspase- 3 in HL-60 cells treated with TBHP. However, these apoptotic events were significantly reduced in the presence of the ethyl acetate fractions of hwanggeumchal sorghum, glutinous sorghum, and barnyard millet grains. In addition, although these apoptotic events were attenuated by a-tocopherol, the attenuation potency appeared to be much lesser extent as compared to the ethyl acetate fractions. Consequently, these results demonstrated that the antioxidant activities of the ethyl acetate fractions obtained from the grains of hwanggeumchal sorghum, glutinous sorghum, and barnyard millet could inhibit the oxidative stress-mediated mitochondrial damage and thus subsequent activation of mitochondria-dependent caspase cascade in HL-60 cells treated with 


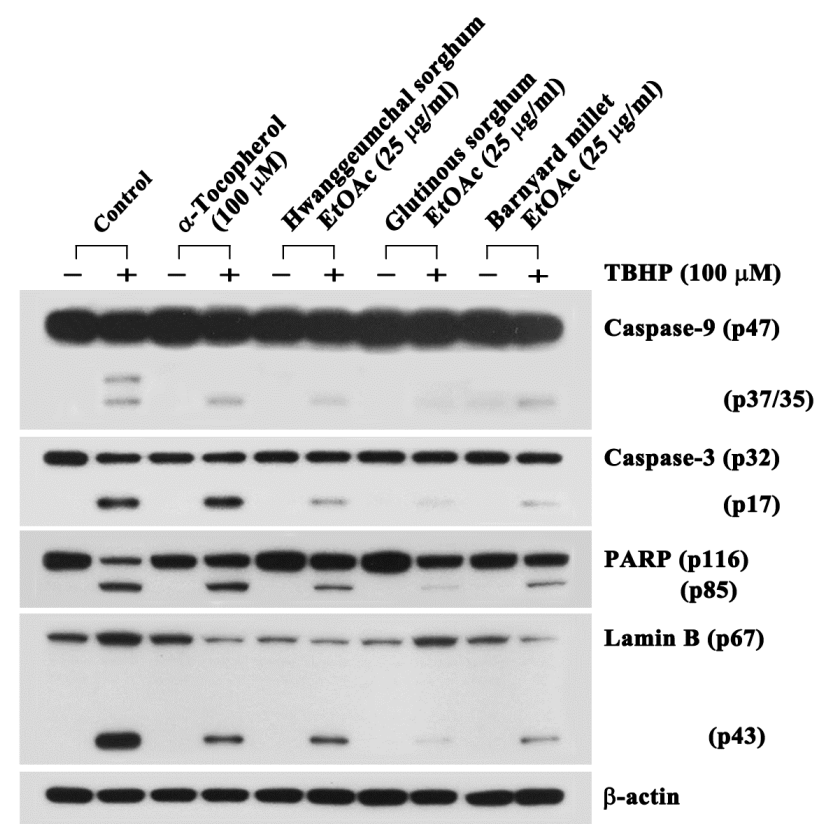

Fig. 4. Inhibitory effect of the ethyl acetate fractions of hwanggeumchal sorghum, glutinous sorghum, and barnyard millet grains on TBHP $(100 \mu \mathrm{M})$-induced activation of caspase- 9 and caspase- 3 , and cleavage of PARP and Lamin B in human HL-60 cells. The cells were incubated at a density of $5 \times 10^{5} / \mathrm{ml}$ with the indicated concentrations of the ethyl acetate fractions for $5 \mathrm{~h}$. Western bot analysis was performed as described in Materials and Methods. A representative study is shown and two additional experiments yielded similar results.

\section{TBHP}

In conclusion, these results show that the $80 \%$ ethanol extracts of hwanggeumchal sorghum (Sorghum bicolor L. Moench cv. Hwanggeumchalsusu), glutinous sorghum (Sorghum bicolor L. Moench cv. Chalsusu), and barnyard millet (Echinochloa esculenta) grains are rich in phenolic components and can exert potent DPPH radical- and ABTS radical-scavenging activities as well as inhibitory activity on lipid peroxidation. In addition, current results indicate that the ethyl acetate fractions prepared from the $80 \%$ ethanol extracts of hwanggeumchal sorghum, glutinous sorghum, and barnyard millet grains can protect human HL-60 cells from oxidative damage-induced apoptotic cell death, and their efficacies are more potent than that of a natural antioxidant a-tocopherol.

\section{Acknowledgements}

This work was carried out with the support of Bio-industry Technology Development Program, Ministry of
Agriculture, Food and Rural Affairs (Grant No. 110133-3), and the support of "Cooperative Research Program for Agriculture Science \& Technology Development (Project No. PJ009865)" Rural Development Administration, Republic of Korea.

\section{References}

1. Adams, J. D., Wang, B., Klaidman, L. K., LeBel, C. P., Odunze, I. N. and Shah, D. 1993. New aspects of brain oxidative stress induced by tert-butylhydroperoxide. Free Radic Biol Med 15, 195-202.

2. Ames, B. N., Shigenaga, M. K. and Hagen, T. M. 1993. Oxidants, antioxidants, and the degenerative diseases of aging. Proc Natl Acad Sci USA 90, 7915-7922.

3. Blois, M. S. 2000. Antioxidant determination by the use of a stable radical. Nature 26, 1199-1200.

4. Bodamyali, T., Stevens, C. R., Blake, D. R. and Winyard, P. G. 2000. Reactive oxygen/nitrogen species and acute inflammation: a physiological process, pp11-16. In: Winyard, P. G., Blake, D. R. and Evans, C. H. (eds.), Free radicals and inflammation. Birkhauser Verlag Basel: Switzerland.

5. Chance, B., Sies, H. and Boveris, A. 1979. Hydroperoxide metabolism in mammalian organs. Physiol Rev 59, 527-605.

6. Cotelle, N., Bernier, J. L., Catteau, J. P., Pommery, J., Wallet, J. C., Gaydou, E. M. 1996. Antioxidant properties of hydroxyflavones. Free Radic Biol Med 20, 35-43.

7. De Beer, D., Joubert, E., Gelderblom, W. C. and Manley, M. 2003. Antioxidant activity of South African red and white cultivar wines: free radical scavenging. J Agric Food Chem 51, 902-909.

8. Elmastas, M., Isildak, O., Turkekul, I. and Temur, N. 2007. Determination of antioxidant activity and antioxidant compounds in wild edible mushrooms. J Food Compos Anal 20, 337-345.

9. Ferreira, I. L., Resende, R., Ferreiro, E., Rego, A. C. and Pereira, C. F. 2010. Multiple defects in energy metabolism in Alzheimer's disease. Curr Drug Targets 11, 1193-1206.

10. Fletcher, A. E. 2010. Free radicals, antioxidants and eye diseases: evidence from epidemiological studies on cataract and age-related macular degeneration. Ophthalmic Res 44, 191-198.

11. Gibson, S. B. 2010. A matter of balance between life and death: Targeting reactive oxygen species (ROS)-induced autophagy for cancer therapy. Autophagy 6, 835-837.

12. Gutteridge, J. M. C. and Halliwell, B. 1994. Antioxidants in nutrition, health and disease. Oxford University Press: Oxford, New York, Tokyo.

13. Ha, Y. D. and Lee, S. P. 2001. Characteristics of proteins in Italian millet, sorghum and common millet. Korean $J$ Postharvest Sci Technol 8, 187-192.

14. Haidara, K., Morel, I., Abalea, V., Gascon Barre, M., Denizeau, F. 2002. Mechanism of tert-butylhydroperoxide induced apoptosis in rat hepatocytes: involvement of mi- 
tochondria and endoplasmic reticulum. Biochim Biophys Acta 1542, 173-185.

15. Hatano, T., Edamatsu, R., Hiramatsu, M., Mori, A., Fujita, Y. and Yasuhara, E. 1989. Effects of the interaction of tannins with co-existing substances. VI: Effects of tannins and related polyphenols on superoxide anion radical and on 1,1-diphenyl-2-picrylhydrazyl radical. Chem Pharma Bull 37, 2016-2021.

16. Ingold, K. U., Webb, A. C., Witter, D., Burton, G. W., Metcalfe, T. A. and Muller, D. P. 1987. Vitamin E remains the major lipid-soluble, chain-breaking antioxidant in human plasma even in individuals suffering severe vitamin E deficiency. Arch Biochem Biophys 259, 224-225.

17. Jain, A., Soni, M., Deb, L., Jain, A., Rout, S., Gupta, V. and Krishna, K. 2008. Antioxidant and hepatoprotective activity of ethanolic and aqueous extracts of Momordica dioica Roxb. leaves. J Ethnopharmacol 115, 61-66.

18. Javanraedi, J., Stushnoff, C., Locke, E. and Vivanco, J. M. 2003. Antioxidant activity and total phenolic content of Iranian Ocimum accessions. Food Chem 83, 547-550.

19. Jun, D. Y., Kim, J. S., Park, H. S., Han, C. R., Fang, Z., Woo, M. H., Rhee, I. K. and Kim, Y. H. 2007. Apoptogenic activity of auraptene of Zanthoxylum schinifolium toward human acute leukemia Jurkat $\mathrm{T}$ cells is associated with ER stressmediated caspase- 8 activation that stimulates mitochondria-dependent or -independent caspase cascade. Carcinogenesis 28, 1303-1313.

20. Kasai, H., Okada, Y., Nishimura, S., Rao, M. S. and Reddy, J. K. 1989. Formation of hydroxydeoxyguanosine in liver DNA of rats following long-term exposure to a peroxisome proliferator. Cancer Res 49, 2603-2605.

21. Kawanishi, S., Hiraku, Y., Murata, M. and Oikawa, S. 2002. The role of metals in site-specific DNA damage with reference to carcinogenesis. Free Radic Biol Med 32, 822-832.

22. Kil, H. Y., Seong, E. S., Ghimire, B. K., Chung, I. M., Kwon, S. S., Goh, E. J., Heo, K., Kim, M. J., Lim, J. D., Lee, D. and $\mathrm{Yu}, \mathrm{C}$. Y. 2009. Antioxidant and antimicrobial activities of crude sorghum extract. Food Chem 115, 1234-1239.

23. Kim, M. S., Oh, I. T., Jun D. Y., Lee, J. Y., Sohn, H. Y., Kwak, D. Y., Seo, M. C., Woo, K. S., Ko, J. Y., Jung, T. W., Nam, M. H., Woo, M. H. and Kim, Y. H. 2013. Anticoagulant and fibrinolytic activities of hwanggeumchal sorghum grains in vitro. J Life Sci 23, 1460-1470.

24. Kroemer, G. and Reed, J. C. 2000. Mitochondrial control of cell death. Nat Med 6, 513-519.

25. Kwak, C. S., Lim, S. J., Kim, S. A., Park, S. C. and Lee, M. S. 2004. Antioxidative and antimutagenicity effects of Korean buckwheat, sorghum, millet, and Job's tears. $J$ Korean Soc Food Sci Nutr 33, 921-929.

26. Kweon, Y. M. and Park, K. Y. 1998. Antimutagenic and anticarcinogenic effect of sorghum. Korean Association Cancer Prev 3, 128-135.

27. Larson, R. A. 1998. The antioxidants of higher plants. Phytochemistry 27, 969-978.

28. Marquart, L., Jacobs, D. R. Jr. and Slavin, J. L. 2000. Whole grains and health. J Am Coll Nutr 19, 289S-290S.
29. Michalak, A. 2006. Phenolic compounds and their antioxidant activity in plants growing under heavy metal stress. Polish J Environ Stud 15, 523-530.

30. Moon, J. K. and Shibamoto, T. 2009. Antioxidant assays for plant and food components. J Agric Food Chem 57, 1655-1666.

31. Osawa, T. A. 1981. Novel type of antioxidant isolated from leaf wax of Eucalytus leaves. Agric Biol Chem 45, 735-739.

32. Park, M. Y., Kim, J. H. and Park, D. S. 2011. Anti-inflammatory activities of hog millet (Panicum miliaceum L.) in murine macrophages through IRAK-4 signaling. Korean $J$ Food Nutr 24, 268-272.

33. Pellegrini, N., Simonetti, P., Gardana, C., Brenna, O., Brighenti, F. and Pietta, P. 2000. Polyphenol content and total antioxidant activity of vini novelli (young red wines): J Agric Food Chem 48, 732-735.

34. Pino, J. A., Regalado, E. L., Rodríguez, J. L, Fernandez, M. D. 2010. Phytochemical analysis and in vitro free-radical-scavenging activities of the essential oils from leaf and fruit of Melaleuca leucadendra L. Chem Biodivers 7, 22812288.

35. Proteggente, A. R., Pannala, A. S., Paganga, G., Van Buren, L., Wagner, E., Wiseman, S., Van De Put, F., Dacombe, C. and Rice-Evans, C. A. 2002. The antioxidant activity of regularly consumed fruit and vegetables reflects their phenolic and vitamin C composition. Free Radic Res 36, 217-233.

36. Sachidanandame, K., Fagan, S. C. and Ergul, A. 2005. Oxidative stress and cardiovascular disease: antioxidants and unresolved issues. Cardiovasc Drug Rev 23, 115-132.

37. Saha, K., Lajis, N. H., Israf, D. A., Hamzah, A. S., Khozirah, S., Khamis, S. and Syahida, A. 2004. Evaluation of antioxidant and nitric oxide inhibitory activities of selected Malaysian medicinal plants. J Ethnopharmacol 92, 263-267.

38. Sahyoun, N. R., Jacques, P. F., Zhang, X. L., Juan, W. and McKeown, N. M. 2006. Whole-grain intake is inversely associated with the metabolic syndrome and mortality in older adults. Am J Clin Nutr 83, 124-131.

39. Singleton, V. L. and Rossi, J. A. 1965. Colorimetry of total phenolics with phosphomolybdic-phosphotungstic acid reagents. Am J Enol Vitic 16, 144-158.

40. Slavin, J. L., Martini, M. C., Jacobs, D. R. Jr. and Marquart, L. 1999. Plausible mechanisms for the protectiveness of whole grains. Am J Clin Nutr 70, 459S-463S.

41. Tada-Oikawa, S, Oikawa, S. and Kawanishi, S. 1998. Role of ultraviolet A-induced oxidative DNA damage in apoptosis via loss of mitochondrial membrane potential and caspase-3 activation. Biochem Biophys Res Commun 247, 693-696.

42. Tait, S. W. and Green, D. R. 2010. Mitochondria and cell death: outer membrane permeabilization and beyond. Nat Rev Mol Cell Biol 11, 621-632.

43. Tirzitis, G. and Bartosz, G. 2010. Determination of antiradical and antioxidant activity: basic principles and new insights. Acta Biochim Pol 57, 139-142.

44. Velioglu, Y. S., Mazza, G., Gao, L. and Oomah, B. D. 1998. Antioxidant activity and total phenolics in selected fruits, vegetables, and grain products. J Agri Food Chem 46, 41134117. 
45. Victor, V. M., Apostolova, N., Herance, R., HernandezMijares, A. and Rocha, M. 2009. Oxidative stress and mitochondrial dysfunction in atherosclerosis: mitochondriatargeted antioxidants as potential therapy. Curr Med Chem 16, 4654-4667.

46. Woo, H. J., Oh, I. T., Lee, J. Y., Jun D. Y., Seu, M. C., Woo, K. S., Nam, M. H. and Kim, Y. H. 2012. Apigeninidin in duces apoptosis through activation of Bak and Bax and subsequent mediation of mitochondrial damage in human promyelocytic leukemia HL-60 cells. Proc Biochem 47, 1861-1871.

47. Zhou, S. H., Fang, Z. X., Lu, Y., Chen, J. C., Liu, D. H. and Ye, X. Q. 2009. Phenolics and antioxidant properties of bayberry (Myrica rubra Sieb. et Zucc.) pomace. Food Chem 112, 394-399.

\section{초록 : 잡곡 유래 에탄올 추출물 및 이의 유기용매 분획들의 항산화 활성 비교평가}

박동화 ${ }^{1} \cdot$ 이승태 ${ }^{1} \cdot$ 전도연 ${ }^{1} \cdot$ 이지영 ${ }^{1} \cdot$ 우미희 ${ }^{2} \cdot$ 김기영 $^{3} \cdot$ 서명철 $^{4} \cdot$ 고지연 ${ }^{3} \cdot$ 우관식 $^{3} \cdot$ 정태욱 $^{3} \cdot$ 곽도연 ${ }^{3} \cdot$ 남민희 $^{3}$. 김영호 ${ }^{*}$

( ${ }^{1}$ 경북대학교 자연과학대학 생명과학부, ${ }^{2}$ 대구가톨릭대학교 약학대학 약학과, ${ }^{3}$ 농촌진흥청 식량과학원 기능 성작물부, ${ }^{4}$ 농촌진흥청 식량과학원 작물환경과)

잡곡류의 항산화활성을 조사하기 위해 국내산 11 종의 잡곡으로부터 $80 \%$ 에탄올 추출물을 얻어 $\mathrm{DPPH}$ - 및 ABTS-라디칼 소거활성을 측정한 결과, 황금찰수수(Sorghum bicolor L. Moench cv. Hwanggeumchalsusu), 찰수수 (Sorghum bicolor L. Moench cv. Chalsusu) 및 식용피(Echinochloa esculenta)의 에탄올 추출물이 다른 잡곡류의 에탄 올 추출물에 비해 높은 라디칼 소거활성을 나타내었다. 이들 황금찰수수, 찰수수 및 식용피의 에탄올 추출물을 n-hexane, methylene chloride, ethyl acetate 및 n-butanol로 분획하였을 때, 대부분의 라디칼 소거활성은 페놀성 화합물이 주로 함유되어 있는 것으로 나타난 ethyl acetate 분획과 butanol 분획에서 집중적으로 확인되었다. 특히, 황금찰수수의 ethyl acetate 분획과 butanol 분획의 라디칼 소거활성은 천연 항산화제인 a-tocopherol에 비해 더 높게 나타났다. 황금찰수수, 찰수수 및 식용피 유래의 ethyl acetate 분획과 butanol 분획은 지질 과산화를 저해하 는 것으로 ferric thiocyanate (FTC)와 thiobarbituric acid (TBA) 방법에 의해 확인되었다. 황금찰수수, 찰수수 및 식용피 유래의 ethyl acetate 분획의 경우, tertiary-butyl hydroperoxide (TBHP) 처리에 의해 HL-60 세포에서 유도 되는 에폽토시스 현상들 즉, sub- $\mathrm{G}_{1}$ 세포 등장, $\Delta \psi_{\mathrm{m}}$ 소실, caspase-9과 caspase-3의 활성화, 그리고 PARP와 lamin $\mathrm{B}$ 의 분해 등을 저해하는 것으로 나타났다. 이러한 결과들은 황금찰수수, 찰수수 및 식용피가 효율적인 항산화 활 성을 지니고 있으며 산화적 손상에 의해 매개되는 에폽토시스를 억제할 수 있음을 보여준다. 아울러 이러한 연구 결과들은, 황금찰수수, 찰수수 및 식용피가 산화적 스트레스로부터 세포를 보호하는 항산화 식이소재가 될 수 있 음을 시사한다. 